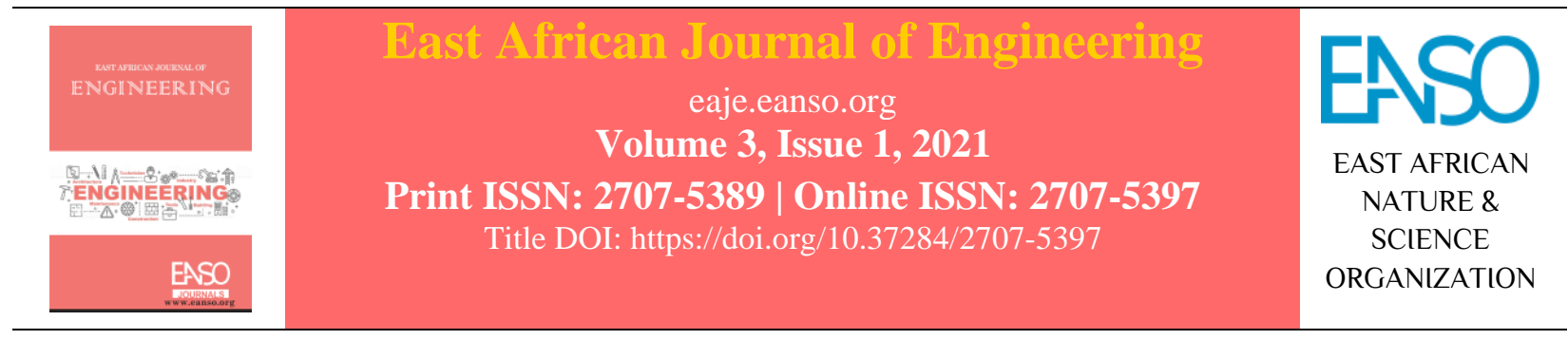

Original Article

\title{
An Evaluation of the Organizational Performance of Local Contractors in Kenya.
}

\author{
Shadrack Mutungi Simon ${ }^{1}$, Dr. Benard Mugwima Njuguna, PhD ${ }^{2} \&$ Dr. Titus Peter Kivaa, PhD \\ ${ }^{1}$ 1Department of Construction Management, Jomo Kenyatta University of Agriculture \& Technology, Kenya, P. O. Box 62000 - \\ 00200 Nairobi, Kenya. \\ 2 2Senior Lecturer at the Centre for Urban Studies, Jomo Kenyatta University of Agriculture \& Technology; Director, Centre for \\ Urban Studies, P. O. Box 62000 - 00200 Nairobi, Kenya. \\ ${ }^{3}$ Senior Lecturer at the Department of Construction Management, Jomo Kenyatta University of Agriculture \& Technology, P. O. \\ Box 62000 - 00200 Nairobi, Kenya. \\ * Author for Correspondence Email: smutungi@jkuat.ac.ke or mutungisimon72@gmail.com.
}

Article DOI: https://doi.org/10.37284/eaje.3.1.289

\section{Publication Date: ABSTRACT}

08 March 2021 Organizational performance is the ultimate measure of the success of any local contractor. It involves the analysis of a firm's performance measured Keywords: against its goals and objectives. Whilst it is generally agreed that the organizational performance of local contractors is insufficient, such a notion is arbitrary and most of the time based on anecdotal evidence. The purpose

dimensions, evaluation,

Kenya,

local contractors, organizational performance. of this research was therefore to establish the level of organizational performance of local contractors here in Kenya. A survey research design was adopted. A questionnaire with the evaluation criteria of organizational performance was used to collect data. The sampling frame included all NCA1, NCA2 and NCA3 contractors. In order to avoid bias in the evaluation process, consultants were included in the survey to obtain an external perspective. The level of organizational performance in local contractors was established at three levels. First, 50 measurable indicators were used. The highest performing indicator was found to be the durability of projects executed by local contractors (mean=7.52). The lowest indicator was established to be the net profit margin of contractors (mean=5.34). The second level involved establishing the level of organizational performance based on the 10 dimensions identified from the literature review. This was achieved by calculating the means of the respective indicators. The best performing dimensions of organizational performance were found to be quality of products (mean=7.308) and client satisfaction (mean=6.923). The least performing dimensions were found to be profitability (mean=5.406) and employee satisfaction (mean=5.683). The final level involved establishing the overall organizational performance of local contractors. This was achieved by calculating the mean of the ten dimensions. The organizational

1 | This work is licensed under a Creative Commons Attribution 4.0 International License. 
performance of local contractors was established to have a percentage score of $63.74 \%$. This was found to be moderately high meaning there was still plenty of room for improvement.

\section{APA CITATION}

Simon, S. M., Njuguna, B. M., \& Kivaa, T . P. (2021). An Evaluation of the Organizational Performance of Local Contractors in Kenya. East African Journal of Engineering, 2(1), 1-21. https://doi.org/10.37284/eaje.3.1.289

\section{CHICAGO CITATION}

Simon, Shadrack Mutungi, Benard Mugwima Njuguna, and Titus Peter Kivaa. 2021. "An Evaluation of the Organizational Performance of Local Contractors in Kenya”. East African Journal of Engineering 2 (1), 1-21. https://doi.org/10.37284/eaje.3.1.289.

\section{HARVARD CITATION}

Simon, S. M., Njuguna, B. M., and Kivaa, T. P. (2021) “An Evaluation of the Organizational Performance of Local Contractors in Kenya", East African Journal of Engineering, 2(1), pp. 1-21. doi: 10.37284/eaje.3.1.289.

\section{IEEE CITATION}

S. M. Simon, B. M. Njuguna, and T. P. Kivaa, "An Evaluation of the Organizational Performance of Local Contractors in Kenya," EAJE, vol. 3, no. 1, pp. 1-21, Nov. 2021.

\section{MLA CITATION}

Simon, Shadrack Mutungi, Benard Mugwima Njuguna, and Titus Peter Kivaa. "An Evaluation of the Organizational Performance of Local Contractors in Kenya." East African Journal of Engineering, Vol. 3, no. 1, Nov. 2021, pp. 1-21, doi:10.37284/eaje.3.1.289.

\section{INTRODUCTION}

Organizational performance is the ultimate measure of the success of any local contractor. It involves the analysis of a firm's performance measured against its goals and objectives. According to Rolstadas (1998), the organizational performance of any system is a complex relationship that involves seven critical performance criteria: efficiency, effectiveness, productivity, quality, quality of work, profitability and innovation. Local contractors in Kenya exhibit the following shortcomings; managerial incompetence at all levels of the firm, poor staffing, lack of access to finance, poor planning, inadequate supervision, and poor engagement with regulatory stakeholders (Moramati Foundation, 2011). Waweru and Omwenga (2015) also found the following weaknesses in Kenyan local contractors; internal and external inefficiencies, reduced profitability and growth, minimal usage of technology, lack of cohesion and fluidity in organizational teams, lack of strategic roadmaps, and weak management structures. Wainaina (2020) observed $73 \%$ of stakeholders in the construction industry cited low coordination levels, lack of enforcement of regulations and inadequate qualified workers among local contractors. All these symptoms are directly linked to the stated performance criteria in an inverse proportionality. This means that local contractors lack the ingredients of enhanced organizational performance. However, whilst it is generally agreed that the organizational performance of local contractors is insufficient, such notion is arbitrary and most of the times based on anecdotal evidence. The purpose of this research was therefore to establish the level of organizational performance of local contractors here in Kenya.

\section{LITERATURE REVIEW}

\section{Evolution of Organizational Performance Measurement}

The concept of organizational performance measurement has evolved over the years. According to Jenatabadi (2015), the history of organizational performance can be discussed in five phases. During the 1960s, Etzioni (1960) believed that good organizational performance could only be realized through frequent assessments to ascertain whether

2 | This work is licensed under a Creative Commons Attribution 4.0 International License. 
or not organizations achieved their set goals and objectives. However, the amount of resources needed to achieve these objectives were not taken into consideration. Chandler (1962) and Thompson (1967) argued that the ultimate organization performance criterion was its growth and long-term survival. The underlying similarity between these three researchers was their focus on 'effectiveness', the company's aim to realize set objectives. Research by Lawrence and Lorsch (1969) provided the concept of organizational performance with another dimension, 'relevancy', which was deemed to be the measure of client satisfaction. Lorsch (1970) introduced a new way of measuring organizational performance which involved analyzing the relationship between the organization, its environment and its employees. The firm was considered to be successful if there was a good relationship between the company and its environment while maintaining employee satisfaction.

It is in the 1970s when the aspect of resource utilization during the attainment of goals was introduced. According to Lupton (1977), the effective organizational performance was characterized by high levels of productivity rate, satisfaction and employee motivation, and low levels of costs, turnover and labour unrests. Katz and Kahn (1978) argued that both 'effectiveness' and 'efficiency' (ratio of output to input) were vital components of overall organizational performance. It is evident from the foregoing that the three most critical dimensions of organizational performance were 'effectiveness,' 'efficiency,' and 'relevancy'.

In the 1980s, the performance was measured as the extent to which organizations, being social systems, could not only consider the ends but also the means (Robbins, 1987). Organizational performance was viewed as an indication of the organizational manner in which it was performing effectively in its attempt to achieve its goals successfully (Cherrington, 1989).

During the 1990s, the focus shifted towards the effectiveness and efficiency of the employee. Adam (1994) considered organizational performance to be heavily reliant on the performance quality of employees. His argument was that in order for any organization to perform highly, there was a need for regular training of employees while exposing them to up-to-date technology and skills. This would ultimately improve the quality of organizational performance. On their part, Harrison and Freeman (1999) argued that a high-performing organization was that which kept the demands of their stakeholders satisfied. Such stakeholders included customers, shareholders and employees. Such arguments supported the earlier raised dimension of 'relevancy'.

Recently in the 2000s, organizational performance revolved mostly around the capability of a firm to efficiently deploy available resources in achieving accomplishments that are consistent with the organization's set objectives while maintaining relevance to its users (Peterson, Gijsbers, \& Wilks, 2003). Such a definition seems to put similar emphasis on the three main dimensions, 'efficiency,' 'effectiveness,' and 'relevancy'.

Cornerstone Learning (2017), an international performance and leadership consulting organization, has made an attempt to analyse the evolution of organizational performance based on a six-point criterion. This has been presented in table 1. They argue that companies of today should be employee-led and leader-supported. This means all the employees should be adequately trained and equipped to lead in every activity they are engaged in. 
Table 1: Evolution of Organizational Performance

\begin{tabular}{|c|c|c|c|c|}
\hline & $\begin{array}{l}\text { Industrial } \\
\text { Age }\end{array}$ & 1970's - 1990's & 2000's - Today & \\
\hline $\begin{array}{l}\text { What's } \\
\text { important }\end{array}$ & The Company & The Process & $\begin{array}{l}\text { The Customer and } \\
\text { the People }\end{array}$ & Network of Teams \\
\hline Focus & $\begin{array}{l}\text { Company } \\
\text { Power }\end{array}$ & $\begin{array}{lr}\text { Operational } & \\
\text { Efficiency, } & \text { Financial } \\
\text { and } & \text { Quality } \\
\text { Engineering } & \end{array}$ & $\begin{array}{l}\text { Agility, } \\
\text { Collaboration and } \\
\text { Change }\end{array}$ & $\begin{array}{l}\text { Disruptive } \\
\text { Thinking and } \\
\text { Sustainability }\end{array}$ \\
\hline Motivation & $\begin{array}{l}\text { Company } \\
\text { Directive }\end{array}$ & $\begin{array}{l}\text { Process-Management } \\
\text { by Objectives }\end{array}$ & $\begin{array}{l}\text { Vision, Mission } \\
\text { and Purpose }\end{array}$ & $\begin{array}{l}\text { Purpose, } \\
\text { empowerment and } \\
\text { Impact }\end{array}$ \\
\hline Examples & $\begin{array}{l}\text { Rockefeller } \\
\text { Carnege } \\
\text { Ford }\end{array}$ & $\begin{array}{l}\text { Jack welch } \\
\text { Peter Drucker } \\
\text { Toyota }\end{array}$ & $\begin{array}{l}\text { Apple } \\
\text { Starbucks } \\
\text { Netflix }\end{array}$ & $\begin{array}{l}\text { Google } \\
\text { Uber } \\
\text { Airbnb }\end{array}$ \\
\hline Accountability & $\begin{array}{l}\text { Company } \\
\text { Executive } \\
\text { Driven }\end{array}$ & $\begin{array}{l}\text { Manager and Process } \\
\text { Driven }\end{array}$ & $\begin{array}{l}\text { Employee-Led } \\
\text { Leader Supported } \\
\text { Organization } \\
\text { Enabled }\end{array}$ & $\begin{array}{l}\text { Purpose-Driven } \\
\text { Employee-Led }\end{array}$ \\
\hline Drivers & The What & The How & The Why & \\
\hline
\end{tabular}

Source: (Cornerstone Learning, 2017)

\section{Dimensions of Organizational Performance}

Organizational performance is a multidimensional concept. Murphy et al. (1996) pointed out that accurate performance measurement was critical to understanding new business failure and success. They carried out their research in two phases wherein the first phase they surveyed the literature on entrepreneurship ranging from the years 19871993 and evaluated the measures and dimensions of performance considered. They noted that the majority of the studies $(60 \%)$ considered either a single or two dimensions in business performance measurement and there was no proper justification for the selection of the criteria. During the second phase of their research, they examined relationships among performance variables and illustrated the extent to which the dimensions of performance exist. They advised that in order to accurately measure the business performance it was necessary to; (i) explicitly state all the performance dimensions under examination, (ii) provide a theory-based rationale for investigating the selected dimensions, (iii) where possible consider multiple performance dimensions, and (iv) consideration of critical control variables such as age, industry and size of the firm.

In order to evaluate the level of organizational performance of local contractors here in Kenya, it was therefore, necessary to first identify the key dimensions of organizational performance. An extensive review of literature identified the following 10 dimensions; quality of products, business efficiency, technical capability, profitability, client satisfaction, managerial capability, employee satisfaction, growth, financial stability and safety performance (Alarcon, Grillo, Freire, \& Diethelm, 2001; Byremo, 2015; Department of Trade and Industry, 2002; Draghici, Popescu, \& Gogan, 2014; Haddadi \& Yaghoobi, 2014; Kaganski, Majak, Karjust, \& Toompalu, 2017; Nudurupati, Arshad, \& Turner, 2007; Pounder, 1999; Puri \& Tiwari, 2014; Ramirez, Alarcon, \& Knights, 2004; Schermerhorn, Hunt, Osborn, \& Osborn, 2004). These dimensions are however concepts that are not easily measured directly. Rather, measurable attributes are used to Commons Attribution 4.0 International License. 
measure the concepts indirectly. Such attributes were also identified from reviewed literature (AlDamen, 2017; Dave, Parmar, Patel and Prajapati, 2017; Hajjat \& Hajjat, 2014; Hatush, 1996; Khatun et al., 2014; Murphy et al., 1996; Myšková \& Hájek, 2017; Rahman \& Alzubi, 2015; Santos \& Brito, 2012; Spacey, 2017)

\section{RESEARCH METHODS}

A survey research design was adopted. A questionnaire with the evaluation criteria of organizational performance was used to collect data. The sampling frame included all NCA1, NCA2 and NCA3 contractors. To avoid bias in the evaluation process, consultants were included in the survey to obtain an external perspective. A total of 612 questionnaires were administered to both contractors (306) and consultants (306). 378 responses were obtained indicating a response rate of $62 \%$. This was deemed adequate based on Mugenda and Mugenda (2003). Both objective and subjective measures were used in evaluating the organizational performance of local contractors.

\section{DATA ANALYSIS}

\section{Demographic Profile of Local Contractors}

\section{(a) Number of permanent staff}

Respondents were asked to report the number of permanent employees in their companies. The results have been presented in figure 1 . The majority (171) of the firms had a workforce of up to 30 employees. The highest (64) reported frequency was 'less than 10' while the lowest (2) frequency was ' $61-70$ '. The frequencies generally reduced with the increasing size of the workforce except for the last category. The approximate mean (average) of the grouped data is 25.89 employees. It can therefore be concluded that most of the firms operate with a lean workforce.

\section{Figure 1: Number of permanent staff}

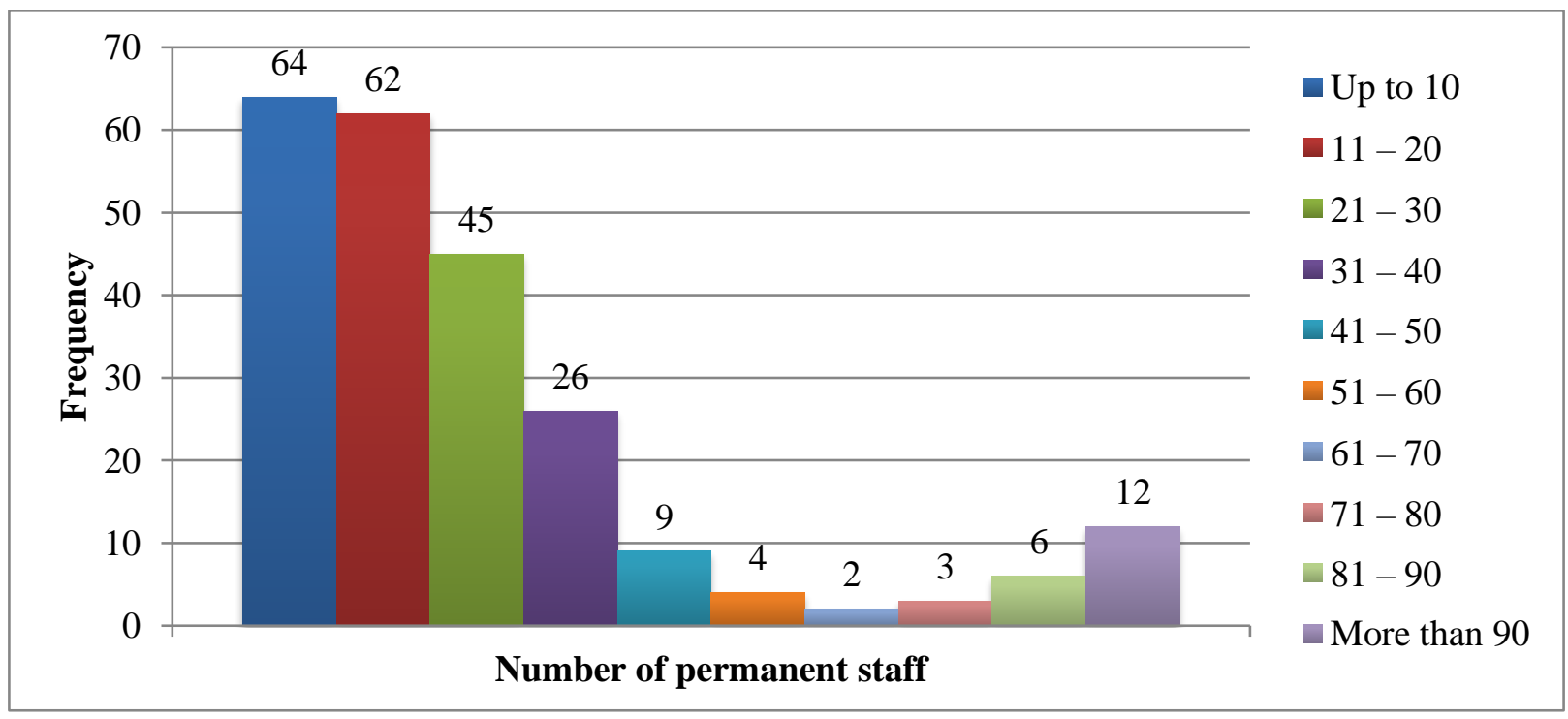

Source: (Author, 2021)

\section{(b) Age of the Firm}

Figure 2 presents data regarding the age of the firms. The category with the highest (62) frequency is ' 11 15 ' years while that with the lowest frequency was
'31-35' years. A majority (189) of the firms were aged between 0 and 20 years. The approximate mean (average) of the ages was found to be 14.4 years.

5 | This work is licensed under a Creative Commons Attribution 4.0 International License. 
Figure 2: Age of the firm

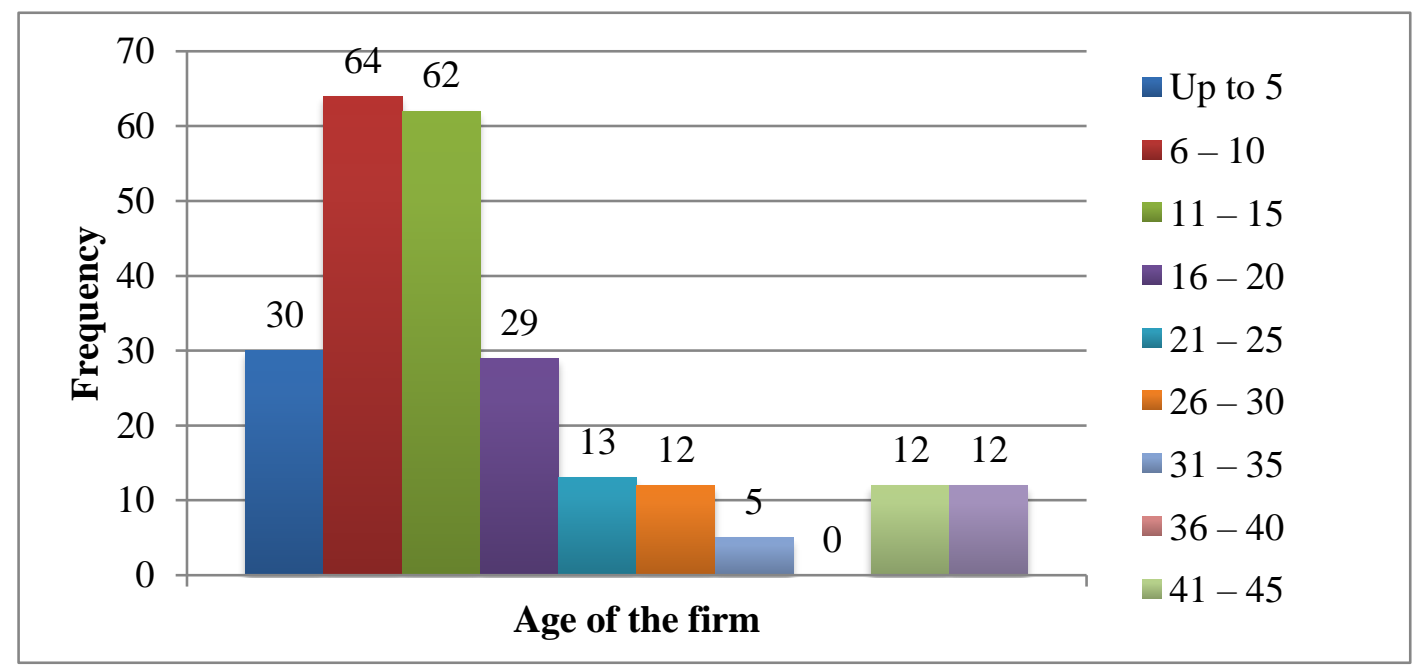

Source: (Author, 2021)

(c) Annual Turnover/Revenue

Based on provided ranges, contractors were required to indicate the average (mean) size of the organization in terms of annual turnover/revenue for the previous five years. 9 contractors failed to disclose this information. As seen in figure 3 , the highest (73) frequency was reported in up to 200 million while the lowest (0) was reported in '1.601 - 1.800 billion'. Only 5 contractors representing $2.2 \%$ reported revenues above 1.8 billion. The overall mean revenue of all the contractors in the three categories was found to be Kshs. 435.84 million. Further analysis of the revenue based on the NCA categories has been presented in figure 4.

Figure 3: Annual Turnover/Revenue

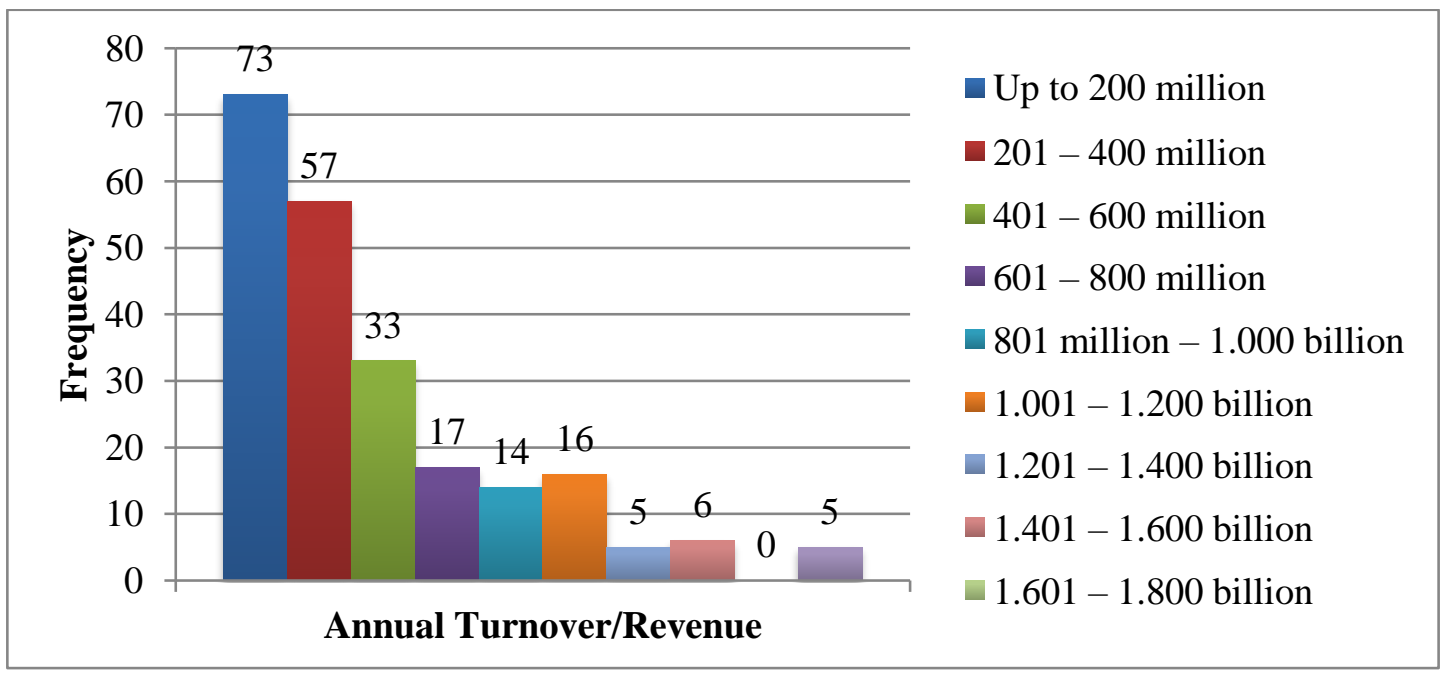

Source: (Author, 2021)

A majority (41) of the contractors who reported their revenues to be less than 200 million were from
NCA3. However, it was also noted that $14 \%$ of the total number of NCA1 contractors engaged in the

6 | This work is licensed under a Creative Commons Attribution 4.0 International License. 
survey reported revenues of less than 200 million while almost half (49.5\%) of these contractors had revenues of less than 600 million. These numbers were considered to be high since according to NCA (2020), NCA1 contractors are supposed to undertake construction jobs worth more than 250 million for specialist works, more than 500 million for building works and more than 750 million for $\mathrm{road} /$ civil works. This clearly indicates that a majority of local contractors registered under NCA1 category are handling relatively smaller projects compared to what they are supposed to. The mean revenue of NCA1 contractors was estimated to be Kshs. 617.14 million compared to Kshs. 373.68 million and Kshs. 193.75million for NCA2 and NCA3 respectively. These figures have been presented in figure 4 . The trend observed was as expected.

Figure 4: Annual Turnover/Revenue per NCA category

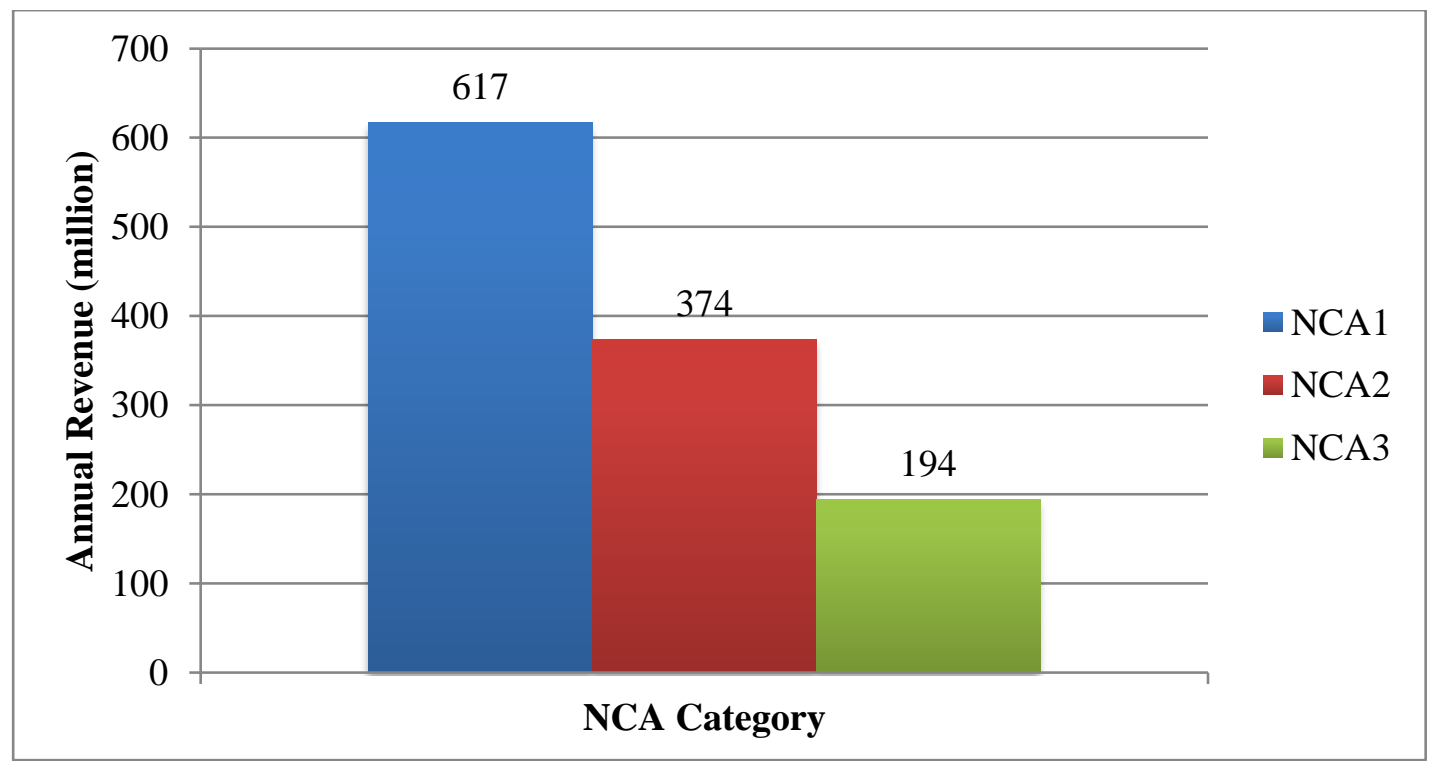

Source: (Author, 2021)

\section{(d) Total Annual Expenditure}

Contractors were also required to indicate the average (mean) of their annual total expenditure for the previous five years. 10 contractors failed to disclose this information. As seen in figure 5, the highest (80) frequency was reported in 'less than
100 million' while the lowest (6) was reported in 'more than 900 million'. The overall mean expenditure of all the contractors in all the three categories was found to be Kshs. 247.33 million. Further analysis of the expenditure based on the NCA categories has been presented in figure 6.

7 | This work is licensed under a Creative Commons Attribution 4.0 International License. 
Figure 5: Total Annual Expenditure

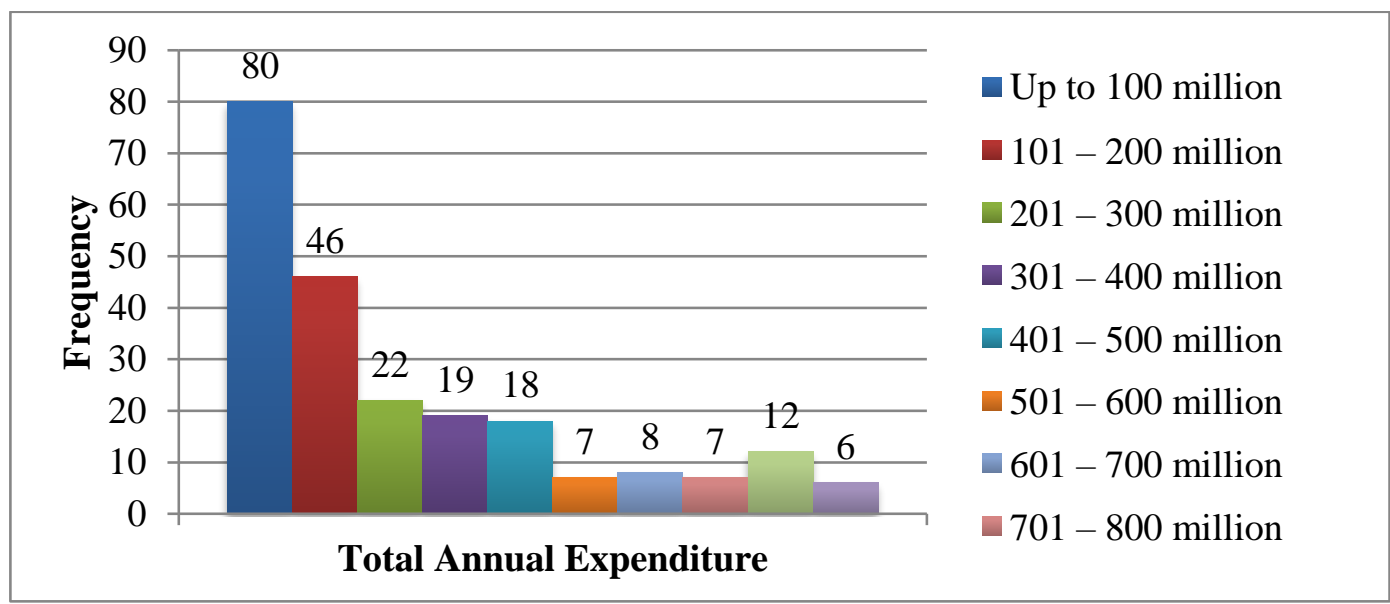

Source: (Author, 2021)

A majority (41) of the contractors who reported their revenues to be less than 100 million were from NCA3 followed by NCA2 $(n=22)$ and NCA1 $(n=17)$ respectively. Out of the 40 contractors who reported total expenditures exceeding 500 million, 33 of them representing $82.5 \%$ were NCA1 contractors. This was expected since contractors in this category were expected to handle a relatively higher volume of construction work. The mean total expenditure of NCA1 contractors was estimated to be Kshs. 351.47 million compared to Kshs. 217.80 million and Kshs. 108.59 million for NCA2 and NCA3 respectively. These figures have been presented in figure 6 . The trend observed was also as expected.

Figure 6: Annual Total Annual Expenditure per NCA category

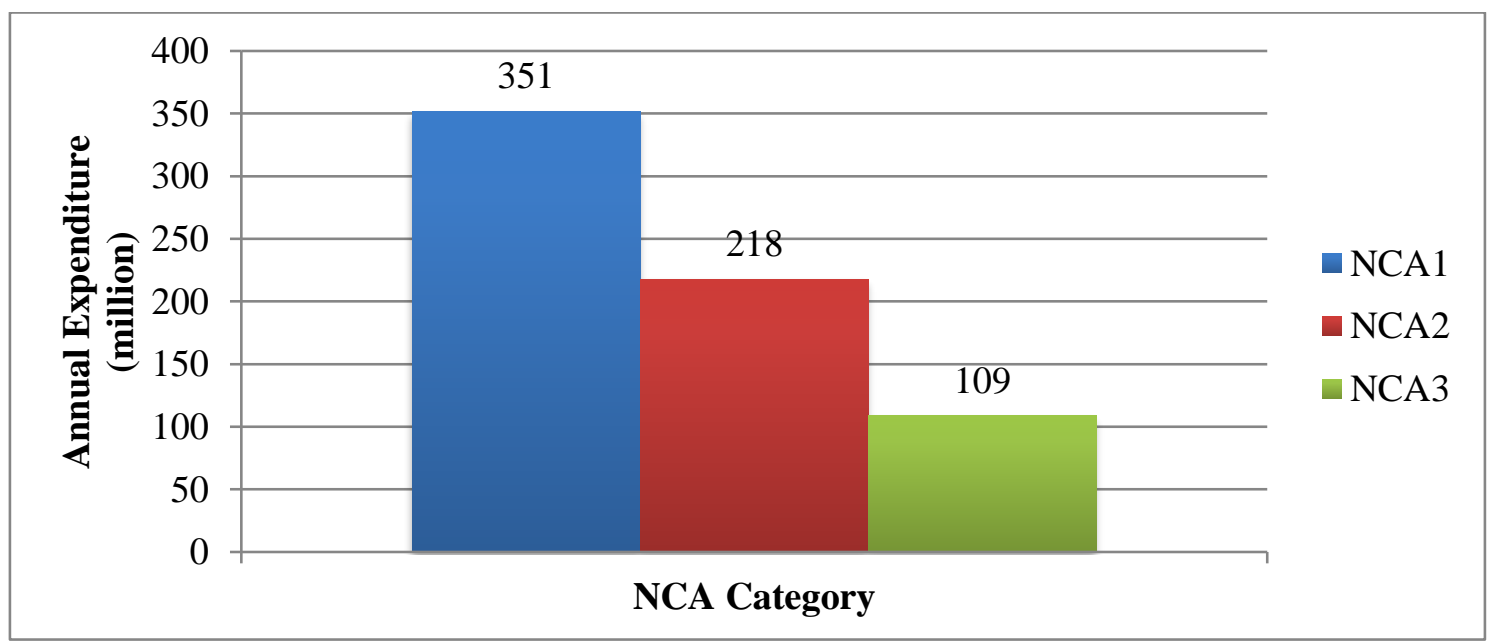

Source: (Author, 2021)

(e) Profitability

Profitability was estimated based on the revenue and expenditure values provided in the two preceding sections. The overall mean revenue of all the contractors in the three categories was found to be Kshs. 435.84 million compared to an expenditure of Kshs. 247.33 million. This meant that the estimated mean profitability for all the three NCA categories combined was Kshs. 188.51 million.

The mean revenues of NCA1, NCA2 and NCA3 contractors were estimated to be Kshs. 617.14

$8 \mid$ This work is licensed under a Creative Commons Attribution 4.0 International License. 
million, Kshs. 373.68 million and Kshs. 193.75 million respectively compared to their total estimated expenditures of Kshs. 351.47 million, Kshs. 217.80 million and Kshs. 108.59 million respectively. Therefore, the approximate profitability for the three NCA categories were Kshs. 265.67 million, Kshs. 155.88 million and Kshs. 85.16 million respectively. These have been presented in figure 7.

\section{Figure 7: Annual Profitability per NCA category}

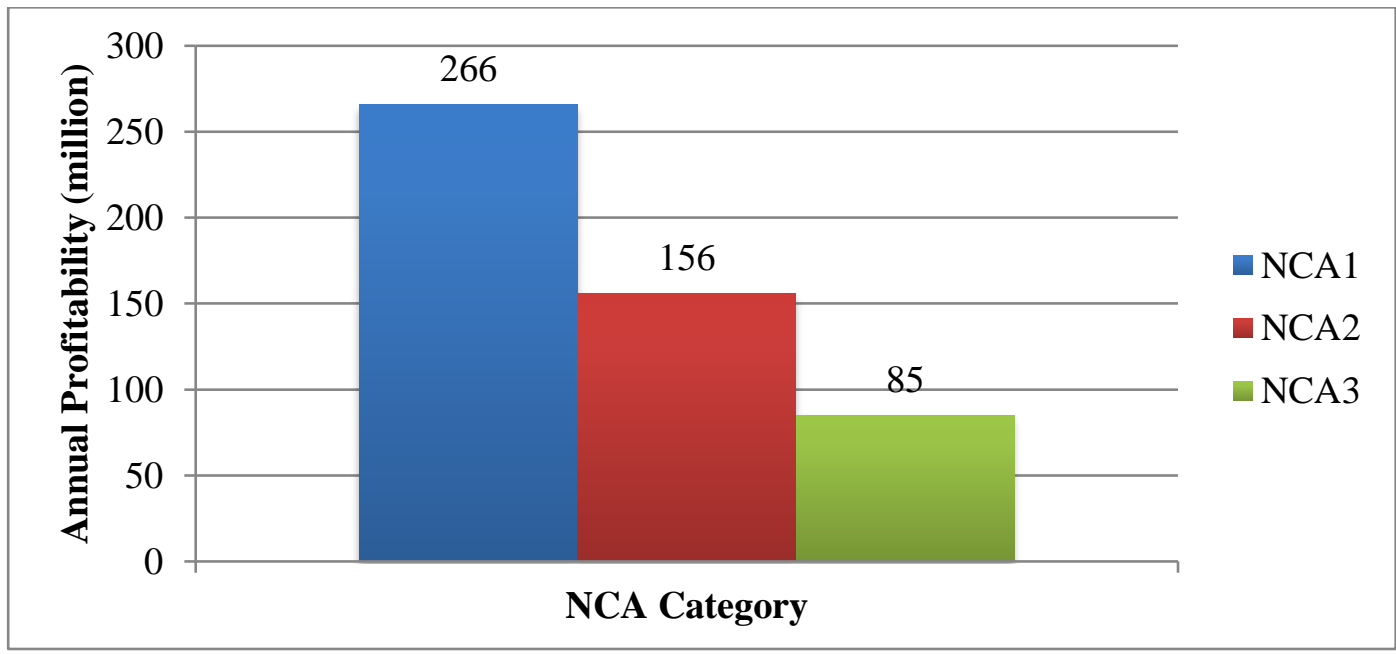

Source: (Author, 2021)

Figure 8 presents the profitability for the three categories expressed as percentages of the revenues. The percentage profitability for NCA1, NCA2 and
NCA3 contractors was estimated to be $43 \%, 42 \%$ and $44 \%$ respectively. The difference in the three categories was very minimal.

Figure 8: Annual Profitability (\%) per NCA category

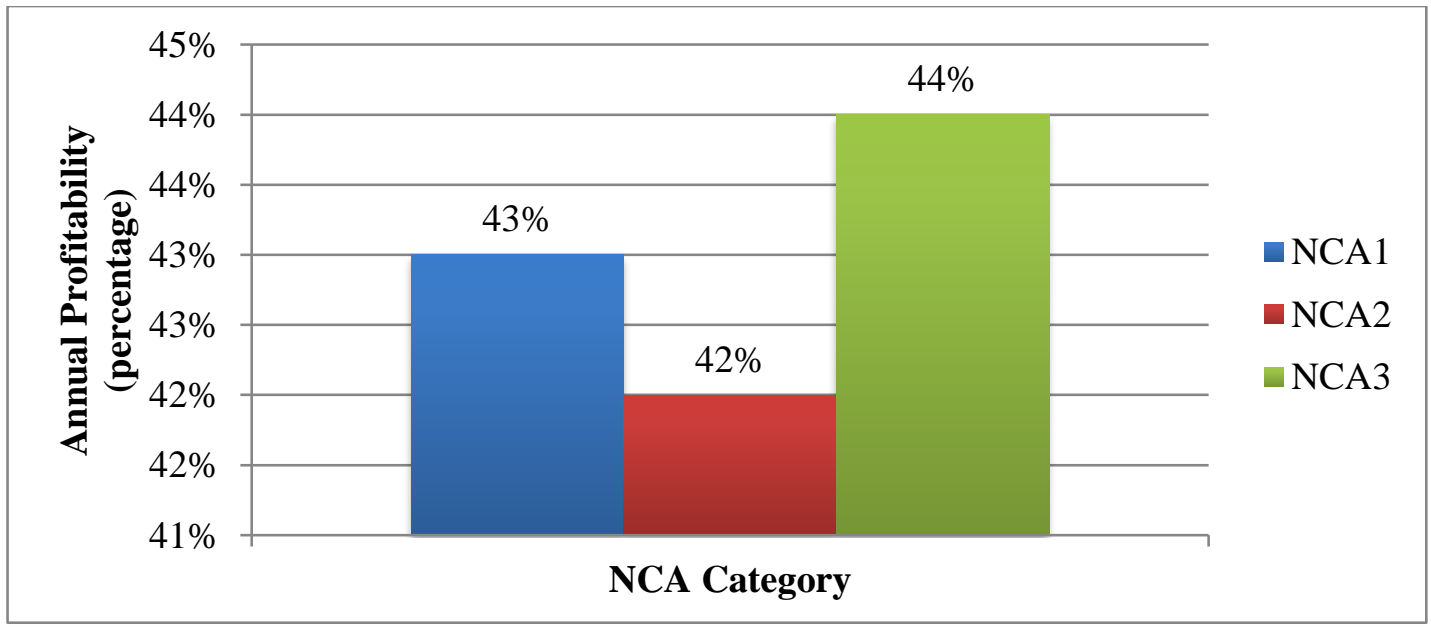

Source: (Author, 2021)

(f) Megaprojects undertaken by NCA1 NCA1 contractors were asked to indicate the Local Contractors proportion of their projects which were worth more

9 | This work is licensed under a Creative Commons Attribution 4.0 International License. 
than Ksh 1 billion for the previous ten years. As seen in the figure, it is evident that approximately half $(\mathrm{n}=53,49.5 \%)$ of the NCA1 contractors almost handle no projects worth more than 1 billion. A big proportion of their projects (91-100\%) are worth less than 1 billion. $20 \%$ of the contractors $(n=21)$ had $11-20 \%$ of their projects being worth 1 billion meaning $80-89 \%$ of their projects were worth less than 1 billion. $13 \%$ of the contractors $(n=14)$ had 21 $30 \%$ of their projects being worth 1 billion meaning $70-79 \%$ of their projects were worth less than 1 billion. The frequencies dropped as the proportionality of the projects worth more than 1 billion increased.

Figure 9: Projects worth more than 1 billion

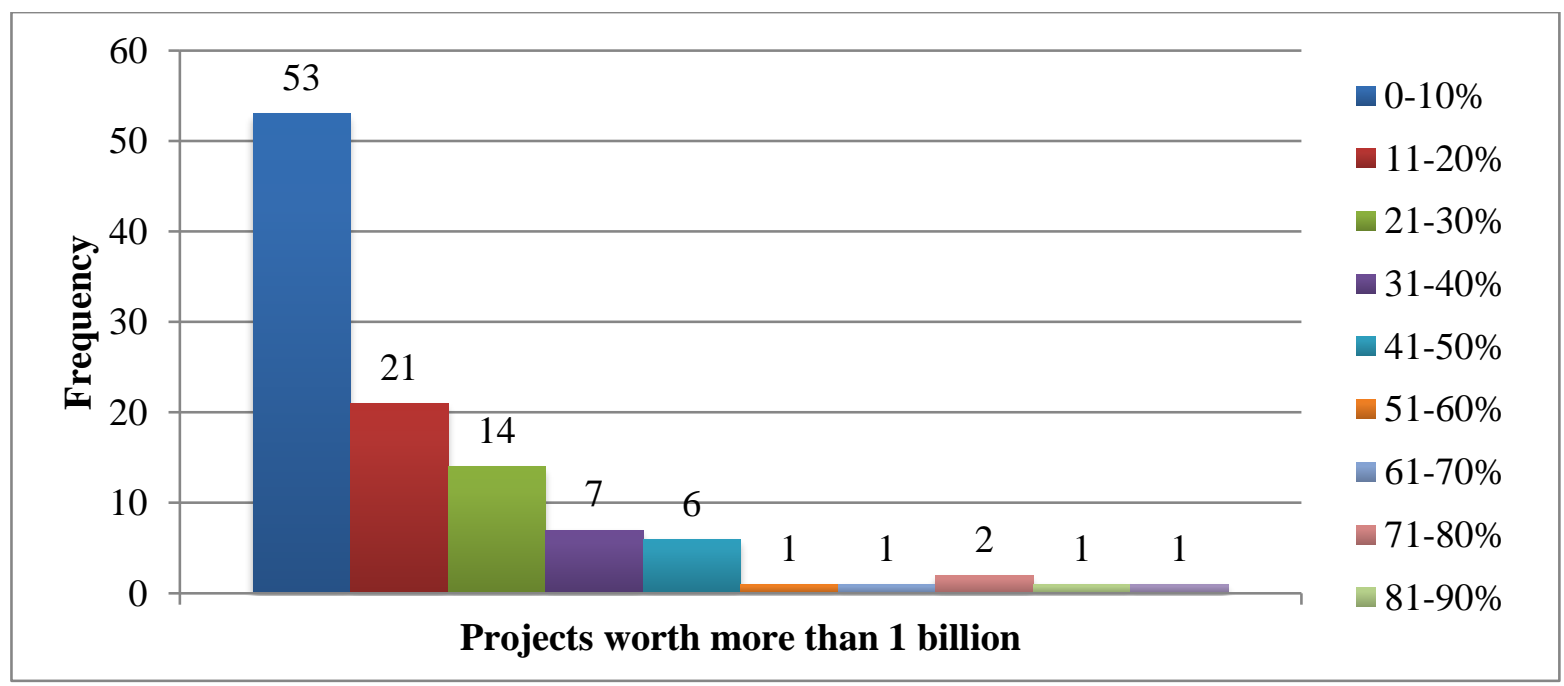

Source: (Author, 2021)

(g) Employee turnover

Respondents were asked to describe the employee turnover in their firms based on a ten year period. $19.5 \%$ of the contractors $(n=41)$ reported the level of employee turnover to be $0-10 \%, 25.2 \%$ of the contractors $(n=53)$ reported $11-20 \%, 21.9 \%$ of the contractors $(n=46)$ reported $21-30 \%$ and $13.3 \%$ of the contractors $(n=28)$ reported $31-40 \% .5 .7 \%$ of the contractors $(n=12)$ reported $41-50 \%, 4.8 \%$ of the contractors $(n=10)$ reported $51-60 \%$ and $2.4 \%$ of the contractors $(n=5)$ reported $61-70 \% .4 .3 \%$ of the contractors $(n=9)$ reported $71-80 \%$ while $2.9 \%$ of $30 \%$. This therefore gives an indication that the employee turnover rate in our case is slightly high but within acceptable range. the contractors $(n=6)$ reported $81-90 \%$. These results have been shown in figure 10 .

The estimated mean employee turnover was $27.8 \%$. Whether voluntary such as resignation or involuntary such as termination due to poor performance, employee turnover is costly and unwanted. A study conducted by Harris, Tang and Tseng (2002) conducted a study between employee turnover and productivity established that the sample mean for studied firms was $18 \%$ but concluded that the optimal employee turnover was

10 | This work is licensed under a Creative Commons Attribution 4.0 International License. 
Figure 10: Employee Turnover

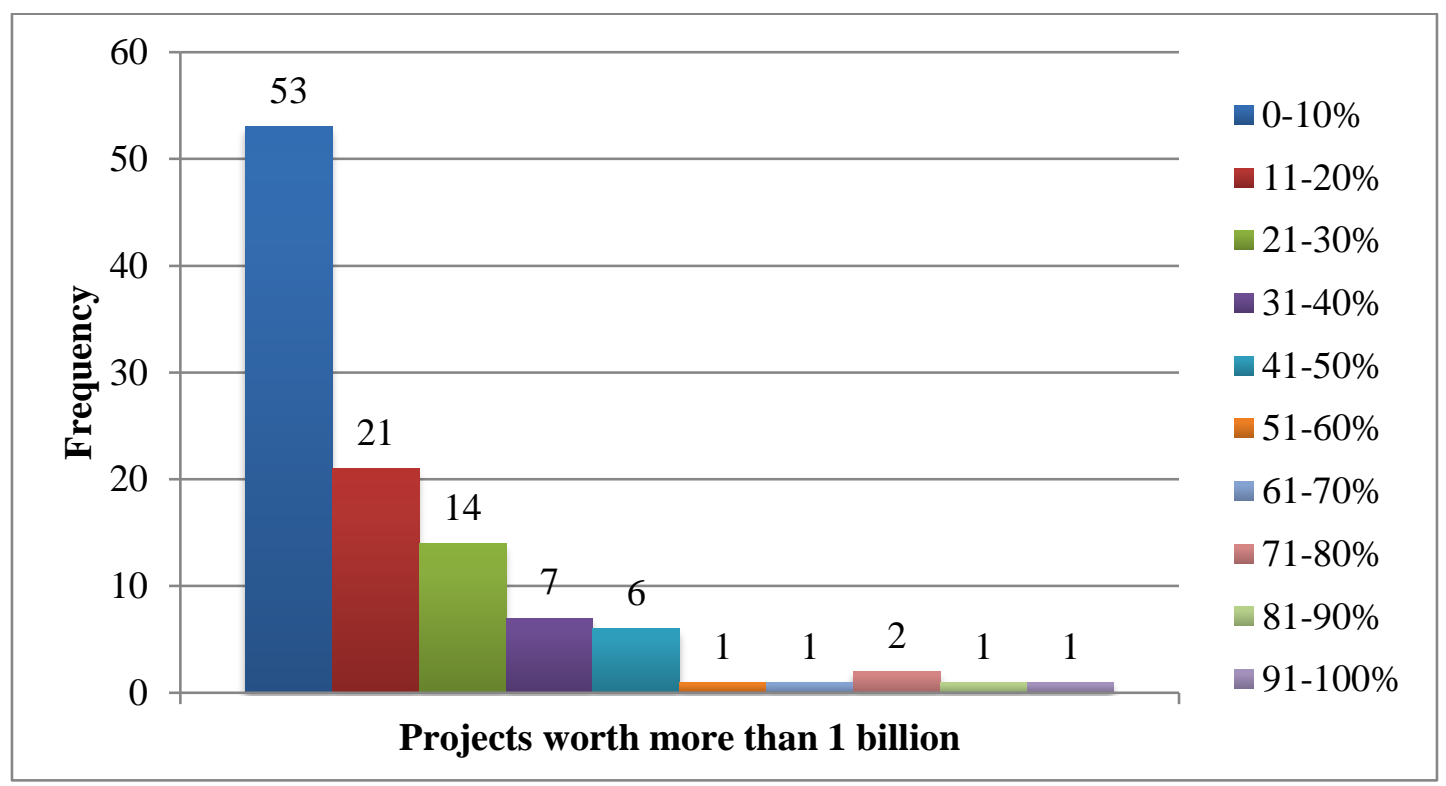

Source: (Author, 2021)

\section{(h) Funding of Working Capital}

Contractors were required to indicate the extent to which their working capital was funded through loans over a period of ten years. Results have been presented in figure $11.11 \% \quad(n=23)$ of the contractors indicated that more than $50 \%$ of their working capital was funded through loans. $20 \%$ $(n=42)$ of the contractors had more than $40 \%$ of their working capital funded by loans. Only $22.8 \%$ $(n=49)$ of the contractors operated almost without (0-10\%) loans. The mean proportion of the working capital funded through loans was established to be $27.73 \%$.

\section{Figure 11: Proportion of Working Capital funded through Loans}

11 | This work is licensed under a Creative Commons Attribution 4.0 International License. 


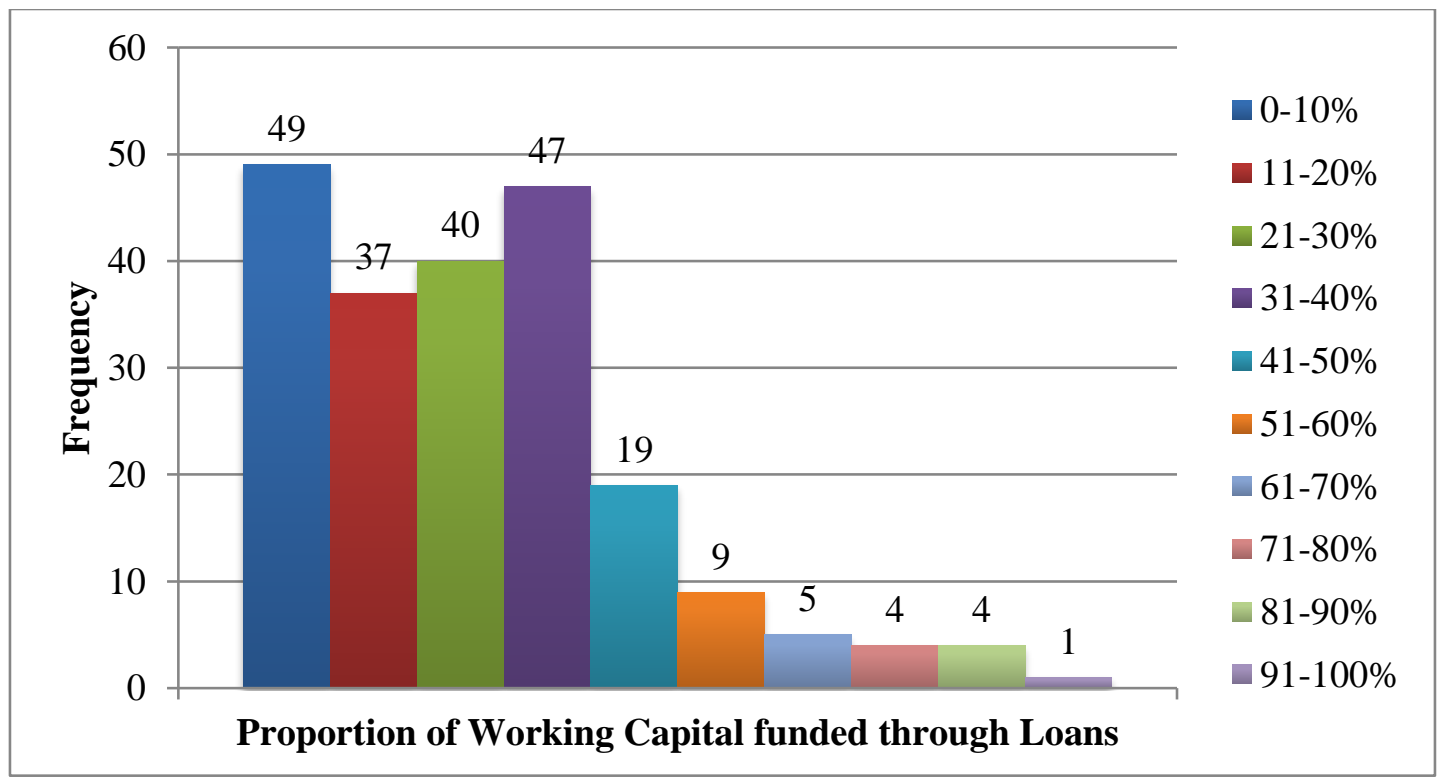

(i) Growth in size of workforce

Based on a five-year period, the growth of the size of the workforce (both permanent and casual) was asked. Results have been presented in figure 12 . The highest frequency $(n=62,28.6 \%)$ was reported in ' $11-20 \%$ ' while the lowest frequency $(\mathrm{n}=0,0.0 \%)$
Source: (Author, 2021)

was reported in '91-100\%'. 64.5\% $(n=140)$ reported growth of up to $30 \%, 25.4 \% \quad(n=55)$ reported growth of between 31 and $60 \%$ while the remaining $10.1 \%(n=22)$ reported growth of above $60 \%$. The estimated mean growth of the workforce was found to be $29.0 \%$.

Figure 12: Growth in size of workforce

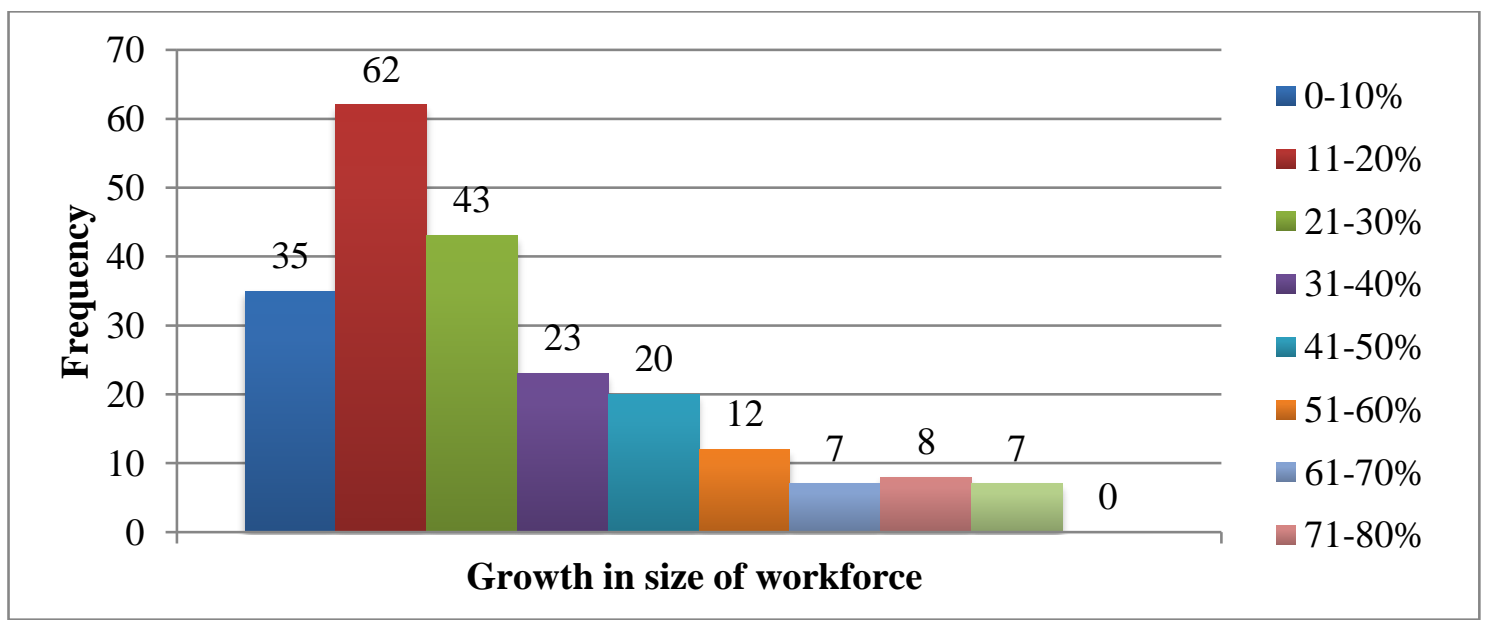

Source: (Author, 2021)

\section{(j) Growth in volume of work}

The growth in the volume of construction work for a period of five years was sought. Results have been presented in figure 13. The highest frequency $(\mathrm{n}=44,20.4 \%)$ was reported in ' $11-20 \%$ '. The lowest frequency $(\mathrm{n}=2,0.9 \%)$ was reported in '91-
$100 \%$, 49.1\% $(\mathrm{n}=106)$ reported growth of up to $30 \%, 34.7 \%(\mathrm{n}=75)$ reported growth of between 31 and $60 \%$ while the remaining $16.2 \% \quad(n=35)$ reported growth of above $60 \%$. The estimated mean growth of the volume of work was found to be $34.9 \%$.

12 | This work is licensed under a Creative Commons Attribution 4.0 International License. 
Figure 13: Growth in volume of work

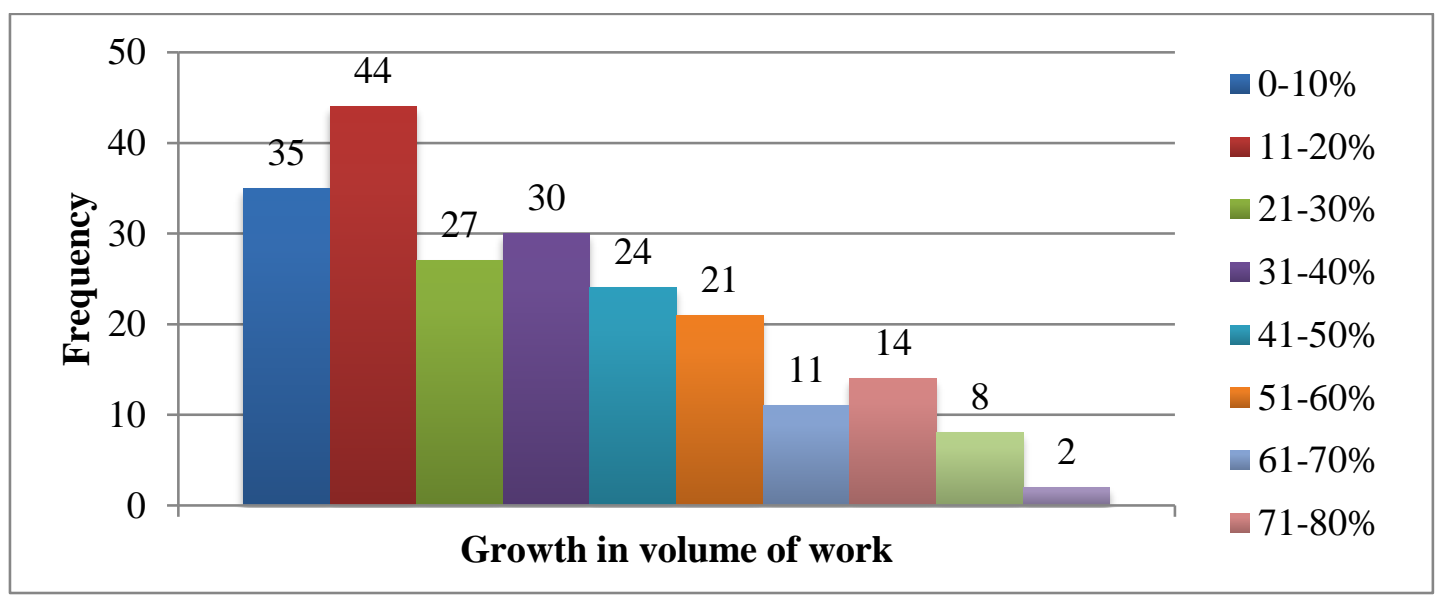

Source: (Author, 2021)

(k) Growth in value of owned equipment Information regarding the growth in value of owned equipment for a period of five years was requested. Results have been presented in figure 14. The highest frequency ( $\mathrm{n}=54,25.0 \%)$ was reported in ' 0 $10 \%$ ' while the lowest frequency $(\mathrm{n}=3,1.4 \%)$ was reported in ' $61-70 \%$ '. 58.3\% $(\mathrm{n}=126)$ reported growth of up to $30 \%, 27.8 \%(n=60)$ reported growth of between 31 and $60 \%$ while the remaining $13.9 \%$ $(n=30)$ reported growth of above $60 \%$. The estimated mean growth of the value of owned equipment was found to be $31.0 \%$.

Figure 14: Growth in value of Equipment

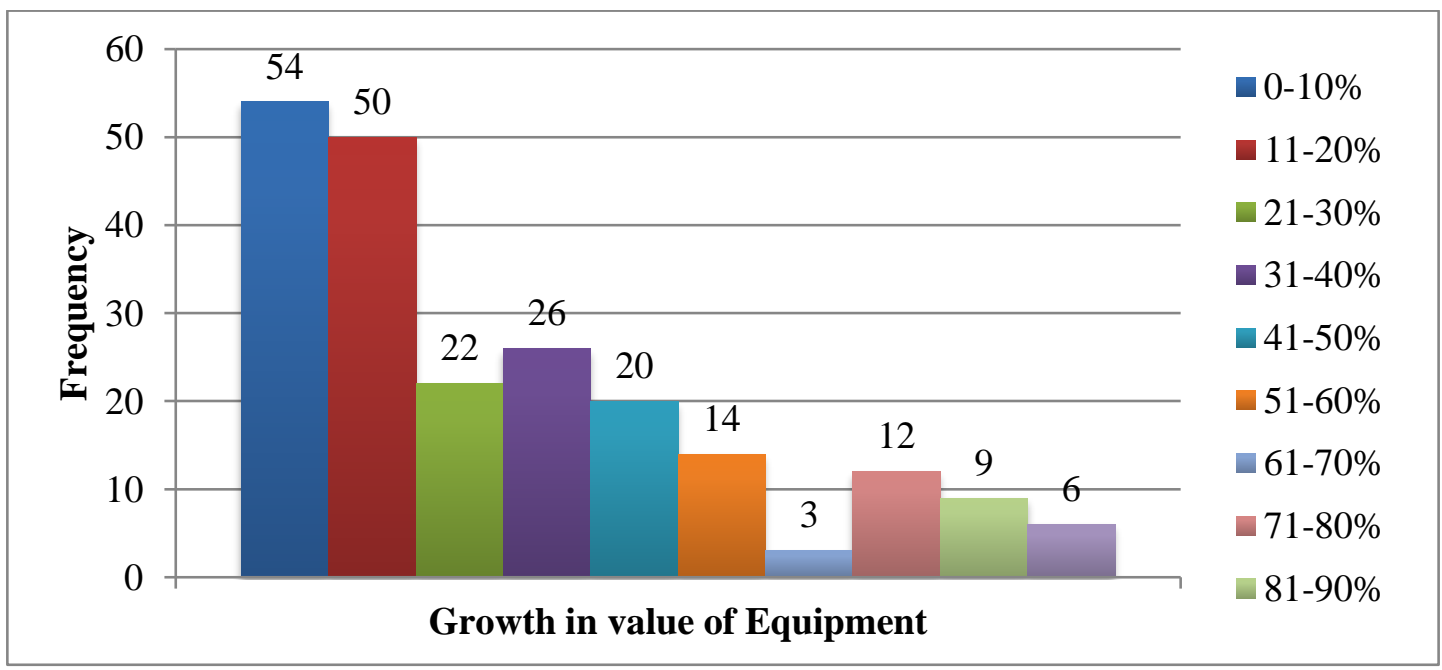

Source: (Author, 2021)

\section{Evaluating the Level of Organizational}

\section{Performance}

This study employed a multidimensional approach where ten dimensions were used to measure the level of organizational performance. Each of the dimensions was measured using five indicators. All the indicators were measured on a numerical rating scale of 1-10 ranging from very low to very high.

\section{(a) Profitability}

13 | This work is licensed under a Creative Commons Attribution 4.0 International License. 
All the five indicators of profitability had almost equal means and standard deviations except for 'return on assets' and 'asset turnover' which had slightly higher standard deviations. The highest mean was 5.72 (gross profit margin) while the lowest mean was 5.26 (return on assets) as shown in table 2. The overall mean for five indicators was 5.406 indicating that the level of profitability among local contractors is moderate. The overall rank indicates the position of the indicator relative to the 50 measured indicators of evaluating the organizational performance of local contractors.

Table 2: Profitability

\begin{tabular}{|c|c|c|c|c|c|c|}
\hline Code Indicator & $\mathbf{N}$ & Min. & Max. & Mean & Std. Dev. & Overall rank \\
\hline PR1 gross profit margin & 378 & 1 & 10 & 5.72 & 1.951 & 40 \\
\hline PR2 operating profit margin & 378 & 1 & 10 & 5.44 & 1.879 & 46 \\
\hline PR3 net profit margin & 378 & 1 & 10 & 5.34 & 1.949 & 48 \\
\hline PR4 return on assets & 378 & 1 & 10 & 5.26 & 2.076 & 49 \\
\hline PR5 asset turnover & 378 & 1 & 10 & 5.28 & 2.140 & 50 \\
\hline
\end{tabular}

Source: (Author, 2021)

(b) Client Satisfaction

Results presented in table 3 indicate that the item with the highest mean (7.13) under client satisfaction was 'service quality' while that with the lowest mean (6.67) was 'adherence to schedule'. The second-lowest mean (6.77) was reported in 'adherence to budget'. This is a reflection of prevailing conditions as Nyangilo, (2012) reported that more than $70 \%$ of the projects handled by local contractors experienced time overruns exceeding $50 \%$ while $50 \%$ of similar projects experience cost overruns exceeding $20 \%$. The overall level of client satisfaction was 6.923 which was considered to be moderately high.

Table 3: Client Satisfaction

\begin{tabular}{|c|c|c|c|c|c|c|}
\hline Code Indicator & $\mathbf{N}$ & Min. & Max. & Mean & Std. Dev. & Overall rank \\
\hline$\overline{\mathrm{CS} 1}$ service quality & 378 & 2 & 10 & 7.13 & 2.002 & 6 \\
\hline CS2 adherence to schedule & 378 & 1 & 10 & 6.67 & 2.161 & 21 \\
\hline CS3 adherence to budget & 378 & 1 & 10 & 6.77 & 2.094 & 19 \\
\hline CS4 communication skills & 378 & 1 & 10 & 6.94 & 2.109 & 12 \\
\hline CS5 personnel skills & 378 & 1 & 10 & 7.11 & 2.028 & 7 \\
\hline
\end{tabular}

\section{(c) Growth}

The indicator with the highest mean (6.20) undergrowth was found to be 'client retention' as shown in table 4. This could be as a result of the relatively high level of client satisfaction reported in previously. The lowest mean (5.59) was reported in 'equipment/assets. The second-lowest mean (5.87) was reported in 'profitability'. The trend in the means of the growth in 'volume of work' (5.71), 'number of employees' (5.67) and 'equipment/assets' (5.59) was almost similar to that measured earlier (demographic profiles) at $34.9 \%$, $29.0 \%$ and $31.0 \%$ respectively. The overall mean of the five indicators was established to be 5.808 and was considered to be moderate.

Table 4: Growth

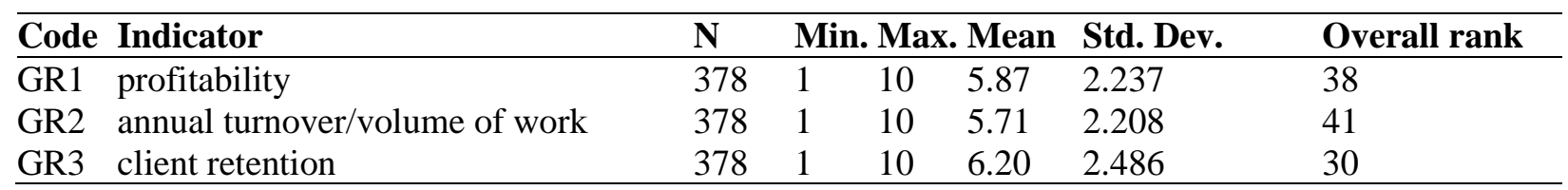

14 | This work is licensed under a Creative Commons Attribution 4.0 International License. 


\begin{tabular}{|c|c|c|c|c|c|c|}
\hline$\overline{\text { Code }}$ & Indicator & $\mathbf{N}$ & Min. Ma & Mean & Std. Dev. & Overall rank \\
\hline$\overline{\mathrm{GR}} 4$ & number of employees & 378 & 10 & 5.67 & 2.384 & 42 \\
\hline GR5 & equipment/assets & 378 & 10 & 5.59 & 2.536 & 45 \\
\hline
\end{tabular}

Source: (Author, 2021)

(d) Technical Capability

As presented in table 5, the item with the highest mean (6.97) under client satisfaction was 'experience (previous works)' while that with the lowest mean (5.96) was 'advancement of electronic software used'. The second-lowest mean (6.03) was reported in 'advancement of electronic hardware used'. This means local contractors do not invest heavily in electronic hardware and software technology as compared to plant and equipment. The overall mean of the five indicators was moderately high at 6.431 .

Table 5: Technical Capability

\begin{tabular}{llllllll}
\hline Code & Indicator & N & \multicolumn{3}{c}{ Min. Max. Mean Std. Dev. } & $\begin{array}{l}\text { Overall } \\
\text { rank }\end{array}$ \\
\hline TC1 & experience (previous works) & 378 & 2 & 10 & 6.97 & 1.989 & 9 \\
TC2 & adequacy of plant \& equipment & 378 & 1 & 10 & 6.34 & 2.166 & 25 \\
TC3 & qualification of personnel & 378 & 2 & 10 & 6.85 & 1.928 & 16 \\
TC4 & advancement of electronic hardware used & 378 & 1 & 10 & 6.03 & 2.149 & 35 \\
TC5 & advancement of electronic software used & 378 & 1 & 10 & 5.96 & 2.249 & 36 \\
\hline
\end{tabular}

Source: (Author, 2021)

\section{(e) Business Efficiency}

'Labour productivity' recorded the highest mean (6.72) followed by 'energy efficiency' at 6.25 as seen in table 6. Wachira (1999) observed that labour productivity is so important that it not only determines the contract period and costs of construction projects but also influences the performance of the entire construction industry here in Kenya. This perhaps explains the focus it's given by most local contractors. The lowest mean (6.10) was recorded in 'revenue per employee'. This gives an indication of a relatively high workforce. Earlier, the annual revenue and number of permanent staff were established to be Kshs. 435.84 million and 25.89 respectively. Though this means that the revenue per employee is Kshs. 16.83 million, it is misleading in the sense that since the construction industry is 'project-based', most of the employees engaged by contractors are casuals. The overall mean of the five indicators was moderately high at 6.293 .

\section{Table 6: Business Efficiency}

\begin{tabular}{llllllll}
\hline Code & Indicator & N & Min. Max. & Mean & Std. Dev. & Overall rank \\
\hline BE1 & labour productivity & 378 & 2 & 10 & 6.72 & 1.955 & 20 \\
BE2 & return on investment in equipment & 378 & 1 & 10 & 6.19 & 1.944 & 31 \\
BE3 & energy efficiency & 378 & 1 & 10 & 6.25 & 1.964 & 27 \\
BE4 & revenue per employee & 378 & 1 & 10 & 6.10 & 1.928 & 34 \\
BE5 & marketing efficiency & 378 & 1 & 10 & 6.21 & 2.057 & 29 \\
\hline
\end{tabular}
Source: (Author, 2021)

\section{(f) Employee Satisfaction}

The highest (5.92) employee satisfaction was reported in 'favourability of working conditions' while the lowest (5.38) was reported in 'reward for excellence in job performance' as seen in table 7 . Generally, the level of employee satisfaction was

15 | This work is licensed under a Creative Commons Attribution 4.0 International License. 
moderate at 5.683. This could be a reason why the employee turnover had been found to be relatively high at $27.8 \%$. High employee satisfaction is associated with low employee turnover and higher employee performance.

\section{Table 7: Employee Satisfaction}

\begin{tabular}{llllllll}
\hline Code Indicator & N & Min. & Max. & Mean & Std. Dev. Overall rank \\
\hline ES1 & remuneration/salary & 378 & 1 & 10 & 5.66 & 2.230 & 43 \\
ES2 & reward for excellence in job performance & 378 & 1 & 10 & 5.38 & 2.424 & 47 \\
ES3 & favourability of working conditions & 378 & 1 & 10 & 5.92 & 2.460 & 37 \\
ES4 & professional growth & 378 & 1 & 10 & 5.82 & 2.471 & 39 \\
ES5 & training and development & 378 & 1 & 10 & 5.63 & 2.621 & 44 \\
\hline
\end{tabular}

Source: (Author, 2021)

\section{(g) Financial Stability}

As presented in table 8, the two highest means were 6.42 and 6.30 for 'credit ratings' and 'access to overdraft facilities' respectively. This means that due to relatively good credit ratings, local contractors are able to access overdraft facilities from local financial institutions. The least financial stability was reported in 'adequacy of working capital'. This explains why $27.73 \%$ of the working capital by local contractors is financed through loans. The second last item was found to be 'net cash flow from projects' with a mean of 6.16. The reduced cash flow could be a result of loan repayments which reduce the net cash flow from projects.

\section{Table 8: Financial Stability}

\begin{tabular}{|c|c|c|c|c|c|c|}
\hline Code Indicator & $\mathbf{N}$ & Min. & Max. & Mean & Std. Dev. & Overall rank \\
\hline FS1 credit ratings & 378 & 1 & 10 & 6.42 & 2.101 & 23 \\
\hline FS2 net value of current assets & 378 & 1 & 10 & 6.23 & 1.996 & 28 \\
\hline FS3 adequacy of working capital & 378 & 2 & 10 & 6.12 & 2.031 & 33 \\
\hline FS4 net cash flow from projects & 378 & 1 & 10 & 6.16 & 1.994 & 32 \\
\hline FS5 access to overdraft facilities & 378 & 1 & 10 & 6.30 & 2.091 & 26 \\
\hline
\end{tabular}

Source: (Author, 2021)

(h) Quality of Products

The means reported in all the indicators were high with the lowest at 7.16 as seen in table 9 . The overall mean for 'quality of products' was 7.303. This is a clear indication that local contractors are capable of achieving good quality in the projects they execute.

Table 9: Quality of Products

\begin{tabular}{|c|c|c|c|c|c|}
\hline Code Indicator & $\mathbf{N}$ & Min. Max. & Mean & Std. Dev. & Overall rank \\
\hline QP1 aesthetics & 378 & 10 & 7.19 & 1.903 & 4 \\
\hline QP2 freeness from defects on completion & 378 & 10 & 7.20 & 1.983 & 3 \\
\hline QP3 fitness for the purpose & 378 & 10 & 7.47 & 1.786 & 2 \\
\hline QP4 support by worthwhile guarantees & 378 & 10 & 7.16 & 1.830 & 5 \\
\hline QP5 durability & 378 & 10 & 7.52 & 1.802 & 1 \\
\hline
\end{tabular}

Source: (Author, 2021)

(i) Managerial Capability

16 | This work is licensed under a Creative Commons Attribution 4.0 International License.
As seen in Table 10, the two highest means were 6.97 and 6.96 for 'effectiveness of strategic 
management' and 'consistency in decision making' resource management'. The overall mean for respectively. The least (6.81) level of managerial managerial capability was found to be 6.907 and capability was reported in 'efficiency in human considered to be moderately high.

Table 10: Managerial Capability

\begin{tabular}{llllllll}
\hline Code & Indicator & N & Min. & Max. & Mean & Std. Dev & $\begin{array}{l}\text { Overall } \\
\text { rank }\end{array}$ \\
\hline MC1 & effectiveness of strategic management & 378 & 1 & 10 & 6.97 & 1.947 & 10 \\
MC2 & consistency in decision making & 378 & 1 & 10 & 6.96 & 1.994 & 11 \\
MC3 & promptness in decision making & 378 & 1 & 10 & 6.87 & 2.033 & 14 \\
MC4 & prudence in financial management & 378 & 1 & 10 & 6.92 & 2.042 & 13 \\
MC5 & efficiency in human resource management & 378 & 1 & 10 & 6.81 & 2.024 & 17 \\
\hline
\end{tabular}

Source: (Author, 2021)

(j) Safety Performance

As seen in table 11, the indicator with the highest (7.09) mean was found to be 'use of personal protective equipment'. Based on regulations provided by the NCA, it is usually mandatory for all personnel on construction sites to use personal

\section{Table 11: Safety Performance}

protective equipment (NCA, 2012). This could be the reason why this indicator had the best performance compared to the rest. The least performed (6.37) indicator was 'availability of health and safety officer'.

\begin{tabular}{|c|c|c|c|c|c|}
\hline Code Indicator & $\mathbf{N}$ & Min. & Max. Mean & Std. Dev. & Overall rank \\
\hline SP1 soundness of health and safety policies & 378 & 1 & 6.87 & 2.032 & 15 \\
\hline SP2 availability of health and safety officer & 378 & 1 & 6.37 & 2.437 & 24 \\
\hline SP3 use of personal protective equipment & 378 & 1 & 7.09 & 1.992 & 8 \\
\hline SP4 use of warning signage, barriers etc. & 378 & 1 & 6.77 & 2.211 & 18 \\
\hline SP5 induction of workers on OHS & 378 & 1 & 6.58 & 2.324 & 22 \\
\hline
\end{tabular}
Source: (Author, 2021)

Figure 15 below is a radar chart of the means of all the 50 indicators used to evaluate the level of organizational performance. Notable low levels of organizational performance were observed in profitability, growth, and employee satisfaction while relatively higher levels were noted in client satisfaction, quality of products and managerial capability.

Figure 15: Overall Profile for the Indicators of Organizational Performance 
East African Journal of Engineering, Volume 3, Issue 1, 2021

Article DOI: https://doi.org/10.37284/eaje.3.1.289

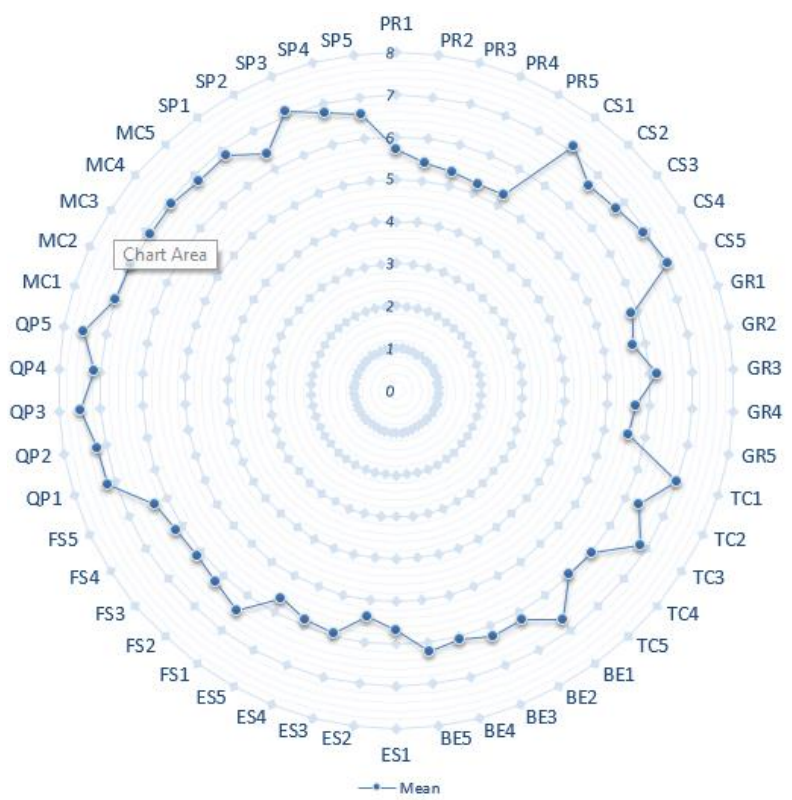

Source: (Author, 2021)

18 This work is licensed under a Creative Commons Attribution 4.0 International License. 
(k) Overall level of Organizational Performance in Local Contractors in Kenya

A summary of the organizational performance across the ten dimensions has been presented in table 12. The three highest performed dimensions were 'Quality of products' (7.308), 'Client satisfaction' (6.923) and 'Managerial capability' (6.907). The three least performed dimensions were 'Financial stability' (6.243), 'Employee satisfaction' (5.683) and 'Profitability' (5.406). This gives an indication of financially struggling local contractors.

Table 12: Dimensions of Organizational Performance

\begin{tabular}{|c|c|c|c|c|c|c|c|}
\hline No. & Dimension & $\mathbf{N}$ & Min & Max & Mean & Std. Dev. & Rank \\
\hline 1 & Profitability & 378 & 1.0 & 10.0 & 5.406 & 1.8595 & 10 \\
\hline 2 & Client satisfaction & 378 & 1.4 & 10.0 & 6.923 & 1.8844 & 2 \\
\hline 3 & Growth & 378 & 1.0 & 10.0 & 5.808 & 2.1616 & 8 \\
\hline 4 & Technical capability & 378 & 1.6 & 10.0 & 6.431 & 1.8403 & 5 \\
\hline 5 & Business efficiency & 378 & 1.2 & 10.0 & 6.293 & 1.7796 & 6 \\
\hline 6 & Employee satisfaction & 378 & 1.0 & 10.0 & 5.683 & 2.2825 & 9 \\
\hline 7 & Financial stability & 378 & 1.8 & 10.0 & 6.243 & 1.8710 & 7 \\
\hline 8 & Quality of products & 378 & 2.0 & 10.0 & 7.308 & 1.7101 & 1 \\
\hline 9 & Managerial capability & 378 & 1.0 & 10.0 & 6.907 & 1.8819 & 3 \\
\hline 10 & Safety performance & 378 & 1.2 & 10.0 & 6.738 & 1.9812 & 4 \\
\hline
\end{tabular}

Source: (Author, 2021)

Local contractors were found to perform poorly in organizational performance of local contractors .in financial aspects (mean=5.938) compared to non- Kenya was obtained using the following formula financial aspects (mean=6.665). The overall level of

$$
O P=\left(\sum_{i=1}^{n} p\right) / n
$$

where ' $n$ ' is the number of dimensions of organizational performance and ' $p$ ' is the individual mean of each of the dimensions.

$$
\begin{gathered}
O P=\frac{(5.40+6.92+5.80+6.43+6.29+5.68+6.24+7.30+6.90+6.74)}{10} \\
O P=\frac{(63.74)}{10} \\
O P=6.374
\end{gathered}
$$

If this was to be converted into a percentage score, the level of organizational performance would be graded as $63.74 \%$. This illustrates a moderately high performance which means there is still plenty of room for improvement.

\section{CONCLUSIONS AND RECOMMENDATIONS}

The following main conclusions were made from the research;
- The organizational performance of local contractors can be evaluated on the basis of ten dimensions namely; profitability, client satisfaction, growth, technical capability, business efficiency, employee satisfaction, financial stability, quality of products, managerial capability, and safety performance.

- The financial performance of local contractors here in Kenya is lower compared to nonfinancial performance.

19 | This work is licensed under a Creative Commons Attribution 4.0 International License. 
- There is a need for improvement in the organizational performance of local contractors here in Kenya.

This research recommended that; local contractors should not only pay attention to financial performance but non-financial performance as well. Both aspects complement each other and are equally significant in the overall organizational performance.

\section{REFERENCES}

Adam, E. E. (1994). Alternative quality improvement practices and organization performance. Journal of Operations Management, 12(1), 27-44.

Al-Damen, R. A. (2017). The impact of Total Quality Management on organizational performance Case of Jordan Oil Petroleum Company. International Journal of Business and Social Science, 8(1), 192-202.

Alarcon, L. F., Grillo, A., Freire, J., \& Diethelm, S. (2001). Learning from collaborative benchmarking in the construction industry. In 9th Conference of International Group for Lean Construction. Singapore.

Byremo, C. (2015). Human Resource Management and Organisational Performance. Unpublished Masters Thesis, University of Oslo.

Chandler, A. (1962). Strategy and structure. Cambridge: MIT Press.

Cherrington, D. J. (1989). Organizational behavior: The management of individual and organizational performance. Boston: Allyn and Bacon.

Cornerstone Learning. (2017). The Evolution of Organizational Performance. Retrieved March 8, 2020 , from https://www.cornerstonelearning.com/news/201 7/2/14/the-evolution-of-organizationalperformance

Department of Trade and Industry. (2002). Construction Products Industry Key Performance Indicators Handbook. London: Construction Products Association.

Draghici, A., Popescu, A.-D., \& Gogan, L. M. (2014). A Proposed Model for Monitoring Organizational Performance. Procedia - Social and Behavioral Sciences, 124(2014), 544-551. https://doi.org/10.1016/j.sbspro.2014.02.518

Etzioni, A. (1960). Two approaches to organizational analysis: A critique and a suggestion. Administrative Science Quarterly, 5(2), 257-278.

Haddadi, F., \& Yaghoobi, T. (2014). Key indicators for organizational performance measurement. Management Science Letters, 4(9), 2021-2030. https://doi.org/10.5267/j.msl.2014.8.019

Hajjat, M. M., \& Hajjat, F. (2014). The Effect of Product Quality on Business Performance in Some Arab Companies. Journal of Emerging Trends in Economics and Management Sciences (, 5(5), 498-508.

Harrison, J. S., \& Freeman, R. E. (1999). Stakeholders, social responsibility, and performance: Empirical evidence and theoretical perspectives. The Academy of Management Journal, 42(5), 479-485.

Hatush, Z. A. (1996). Contractor Selection using Multiattribute Utility Theory. Unpublished $\mathrm{PhD}$ Thesis, University of Salford, Salford, UK.

Jenatabadi, H. S. (2015). An Overview of Organizational Performance Index: Definitions and Measurements The electrochemical capacitive behavior of polymer-based nanocomposites View project An Overview of Organizational Performance Index: Definitions

20 | This work is licensed under a Creative Commons Attribution 4.0 International License. 
and Measurements, (May). https://doi.org/10.13140/RG.2.1.4298.3849

Kaganski, S., Majak, J., Karjust, K., \& Toompalu, S. (2017). Implementation of Key Performance Indicators Selection Model as Part of the Enterprise Analysis Model. Procedia CIRP, 63, 283-288.

https://doi.org/10.1016/j.procir.2017.03.143

Katz, D., \& Kahn, R. L. (1978). The social psychology of organizations. New York: Wiley.

Khatun, K. M., Islam, M. A., \& Tehseen, S. (2014). Determinants of organizational performance: A case study on an electronic company in Malaysia. Advances in Environmental Biology, 8(9), 440-449.

Lawrence, P., \& Lorsch, J. (1969). Organization and Environment: Managing Differentiation and Integration. Boston: Harvard University Press.

Lorsch, J. (1970). Introduction to the structural design of organizations: Organizational structure and design.

Lupton, T. (1977). Organizational Behavior and Performance. London: Macmillan Press.

Moramati Foundation. (2011). The Kenyan Construction Industry. Nairobi.

Mugenda, O. ., \& Mugenda, A. . (2003). Research methods: Quantitative and Qualitative Approaches. Nairobi: African Centre for Technology Studies.

Murphy, G. B., Trailer, J. W., \& Hill, R. C. (1996). Measuring performance in entrepreneurship research. Journal of Business Research, 36(1), 15-23. https://doi.org/10.1016/01482963(95)00159-X

Myšková, R., \& Hájek, P. (2017). Comprehensive assessment of firm financial performance using financial ratios and linguistic analysis of annual reports. Journal of International Studies, 10(4), 96-108. https://doi.org/10.14254/2071$8330.2017 / 10-4 / 7$

NCA. National Construction Authority Draft Regulations, 84 § (2012). Kenya. Retrieved from http://nca.go.ke/wpcontent/uploads/2017/05/NCA-Regulations2014-2.pdf

Nudurupati, S., Arshad, T., \& Turner, T. (2007). Performance measurement in the construction industry: an action case investigating manufacturing methodologies. Computers \& Industrial Engineering, 58, 667-676.

Nyangilo, A. O. (2012). An assessment of the organization structure and leadership effects on construction projects' performance in Kenya: a case study of public building projects within Nairobi region. Unpublished Masters Thesis, University of Nairobi.

Peterson, W., Gijsbers, G., \& Wilks, M. (2003). An organizational performance assessment system for agricultural research organizations: concepts, methods, and procedures (ISNAR Research Management Guidelines No. 7).

Pounder, J. (1999). Organizational effectiveness in higher education. Educational Management Administration \& Leadership, 27(4), 389-400. Retrieved from http://dx.doi.org/10.1177/0263211X990274006

Puri, D., \& Tiwari, S. (2014). Evaluating The Criteria for Contractors' Selection and Bid Evaluation. International Journal of Engineering Science Invention, 3(7), 44-48. Retrieved from www.ijesi.org

Rahman, A., \& Alzubi, Y. (2015). Exploring Key Contractor Factors Influencing Client Satisfaction Level in Dealing with Construction Project: an Empirical Study in Jordan. International Journal of Academic Research in

21 This work is licensed under a Creative Commons Attribution 4.0 International License. 
Business and Social Sciences, 5(12), 109-126. https://doi.org/10.6007/ijarbss/v5-i12/1935

Ramirez, R. R., Alarcon, L. F. C., \& Knights, P. (2004). Benchmarking system for evaluating management practices in the construction industry. Journal of Management in Engineering, 20(3), 110-117.

Robbins, S. P. (1987). Organizational Theory: Structure, Design, and Application. San Diego: Prentice-Hall.

Rolstadas, A. (1998). Entreprise Performance Measurement. International Journal of Operations and Production Management, 18, 910.

Santos, J. B., \& Brito, L. A. L. (2012). Toward a subjective measurement model for firm performance. BAR - Brazilian Administration Review, 9(SPL. ISS), 95-117. https://doi.org/10.1590/S1807-

76922012000500007

Schermerhorn, J. R., Hunt, J. G., Osborn, R. N., \& Osborn, R. (2004). Core concepts of organizational behavior. London: John Wiley \& Sons Inc.

Spacey, J. (2017). 7 Types of Business Efficiency. Retrieved September 11, 2020, from https://simplicable.com/new/business-efficiency

Thompson, J. (1967). Organization in Action. New York: McGraw-Hill.

Wachira, I. N. (1999). Labour productivity in the Kenyan construction industry. In P. Bowen \& R. Hindle (Eds.), CIB W55 \& W65 Joint Triennial Symposium (pp. 1-9). Cape Town. Retrieved from http://scholar.google.com/scholar?hl=en\&btnG $=$ Search\&q=intitle:LABOUR+PRODUCTIVIT Y+IN+THE+KENYAN+CONSTRUCTION+I NDUSTRY\#1
Wainaina, W. (2020, December 5). Local contractors starved of jobs as foreign firms reap big. The Standard. Retrieved from https://www.standardmedia.co.ke/business/artic le/2001396287/local-contractors-starved-ofjobs-as-foreign-firms-reap-big

Waweru, P. K., \& Omwenga, J. (2015). The Influence of Strategic Management Practices on Performance of Private Construction Firms in Kenya. International Journal of Scientific and Research Publications, 5(6), 1-36. Retrieved from www.ijsrp.org 